\title{
BEHAVIOURISM? COGNITIVE THEORY? HUMANISTIC PSYCHOLOGY? - TO HULL WITH THEM ALL!
}

\author{
D. E. BERLYNE \\ University of Toronto
}

\begin{abstract}
Some curious features of the current psychological scene are briefly examined. They include the notion that psychology is undergoing a paradigm shift and that the paradigm due for suppression can be identified with "behoviourism". It is suggested that, although a return to Hull's behoviour theory can scarcely be advocated, some characteristics of Hull's approach which have now been widely abondoned, could with advantage be revived. These are (a) the objective of integration, (b) attention to motivational problems and (c) the recognition of the important contrasts, as well as continuities, between behaviour controlled by symbolic processes and behaviour not so controlled. These might enable us to avoid opposite shortcomings of contemporary Skinnerian and neo-cognitivist positions.
\end{abstract}

\section{RESUME}

Examen rapide de quelques caractéristiques de la situation actuelle en psychologie. On y retrouve notamment l'idée que la psychologie est en voie de changer de modèle et que le modèle appelé à disparaître peut s'identifier au "behaviorisme". La suggestion est faite que, même si un retour à la théorie behavioriste de Hull peut à peine se défendre, il n'en reste pas moins que certaines de ses caractéristiques largement abandonnées aujourd'hui pourraient avantageusement renaître: a) le souci d'intégration; b) l'attention portée aux problèmes de motivation; c) la reconnaissance des continuités ainsi que des contrastes importants entre le comportement quì est contrôlé par des processus symboliques et le comportement qui ne l'est pas. On devrait pouvoir cinsi parer aux déficiences inconciliables des positions skinnériennes et néo-cognitivistes contemporaines.

\section{PARADIGMS}

During the last few years, the progress of psychology has been marked by alarming jolts and grinding noises. And if it is a sign of crisis to have people saying repeatedly that there is a crisis, then psychology is clearly in a state of crisis. Many commentators, having read Kuhn's book (1962), The structure of scientific revolutions, feel that they can recognise what is happening (e.g., Boneau, 1974; Deese, 1972; Dember, 1974; Gardiner, 1973; Giorgi, 1970; Palermo, 1971). Psychology is undergoing a paradigm shift.

A high proportion of psychologists seem curiously unaffected by all this, as they doggedly pursue their work in their accustomed manner, confining their contacts

1This article is $a$ slightly expanded version of the Presidential Address to Division 1 at the meeting of the American Psychological Association, New Orleans, September 2, 1974. Its preparation was facilitated by research grant A-73 from the National Research Council. to circles of like-minded colleagues. They are all confident of riding the wave of the future, oblivious of the maelstroms that are about to open beneath them. But apocalyptic portents are apparent at the abrasive interfaces - where psychologists complain about their colleagues' shortcomings to the beginning student or to the general public and where freelance intellectuals and representatives of other disciplines voice their unflattering impressions of contemporary psychology.

The paradigm that is in the process of being abandoned is variously labelled "behaviourism," "S-R psychology," "mechanism," and "reductionism." At least, these are some of the politer things that it is called. And the preferable paradigm that is supplanting it is variously identified with "cognitive theory" or "humanistic psychology." These two expressions are, of course, by no means synonymous, and each of them is used by different authors to 
denote very different positions and kinds of activity.

In the midst of the current turmoil, it is almost impossible for us to gain a balanced view of what is going on. For that, we need the detached perspective of posterity. The best we can do is to imagine some future time, say 100 years from now, when the history of psychology will be as well developed a discipline as the histories of art and philosophy have been for some time and as the history of the physical sciences is just becoming. We must try to see things through the eyes of a young trainee in this discipline - let us call him John Q. Graduate Student - who has been able to fulfil the rigorous entrance requirements, including above-average credulity and a hypertrophied sense of humour, and has gone through the requisite apprenticeship.

He will look back on the early 1970's, known as the "period of the great paradigm shift," with particular warmth, but, as with all good graduate students, a few questions will occur to him and he will want to look into them.

First, did psychology at that time have a paradigm to repudiate? A paradigm is initially defined in Kuhn's book (1962, p. 10) as an "achievement that is sufficiently unprecedented to attract an enduring group of adherents away from competing modes of scientific activity and sufficiently openended to leave all sorts of problems for the re-defined group of practitioners to resolve." Kuhn (p. 13) recognises pre-paradigm stages in science. Physical optics before Newton in a case in point, and he writes, "being able to take no common body of belief for granted, each writer on physical optics felt forced to build his field anew from its foundations. In so doing, his choice of supporting observation and experiment was relatively free, for there was no standard set of methods or phenomena that every optical writer felt forced to employ and explain. Under these circumstances, the dialogue of the resulting books was often directed as much to the members of other schools as it was to nature." That description sounds uncomfortably familiar and certainly fits much of psychology at present. Nevertheless, particular areas of research in psychology have certainly had paradigms that conform to Kuhn's definition. But this is different from the existence of a paradigm for psychology as a whole.

In later passages of his book, Kuhn associates paradigms with principles on which scientists are for a while agreed. But psychologists have never been noted for consensus or for approval of one another's work. John Q. Graduate Student will therefore be moved to ask himself the next question. Was there more paradigm shifting in psychology in the early 1970's than at previous times? Was psychology ever not in a state of crisis? In the third quarter of the 20th century, fruitful new paradigms were appearing in such fundamental areas as learning, perception, motivation and thinking. But it could be argued that new paradigms in these and other areas had appeared every 10 years or so since their inception. As long ago as 1937, Spearmar (p. 5) wrote, "But what really may startle and even disturb us is that those very psychologists who profess - and are everywhere admitted - to bring such a vast accretion of knowledge and power, are nevertheless in extreme discord and conflict with one another! .... What would the world say if presented with ten rival physics or botanies or chemistries? Curiously too this clash of schools is no special characteristic of modern times. So far back as history goes, there seem to have been conflicts of a similar kind, if on a smaller scale." There is no lack of comparable quotations from earlier and later authors. That psychology has had a history of uninterrupted upheaval making the San Andreas fault look like permafrost can scarcely be questioned.

\section{BEHAVIOURISM}

John will then be brought to his third set of questions. What was behaviourism? Was it a paradigm, and if so, were its shortcomings severe enough to call for its supersession? He will find no lack of writers who were willing to characterise behaviourism for him. One British psychologist, Rowan (1973), claims to have shown that behaviourism is "wrong theoretically, wrong technically, wrong morally and wrong politically." Von Bertalanffy (quoted in Koestler, 1967, p. 352) described it as a "sterile and pompous scholasticism which, with blinkers of preconceived notions or super- 
stitions, doesn't see the obvious; which covers the triviality of its results and ideas with a preposterous language bearing no resemblance to normal English or sound theory, and which provides modern society with the techniques for the progressive stultification of mankind." The stultification of mankind, as even a cursory reading of history will show, has been doing pretty well for thousands of years. There is little sign that its practitioners have ever needed to take lessons from behaviourists.

Behaviourism has been represented as a tissue of elementary errors. It has been denounced with ad hominem arguments, ethical and political arguments, philosophicolinguistic arguments, metaphysico-theological arguments, and arguments of Chomskyan inspiration. It has been charged with aping physics to an extent that is inappropriate to the subject matter of psychology. It has been taken to task for not keeping abreast of the revolutions that have occurred in 20th-century physics (which presumably means that it has not been aping physics enough!). It has been taxed with categorising behaviour in ways that are not correct or meaningful. All these objections call for careful examination, and the question arises, as with many patrons of taverns, of whether they will survive large doses of what they call for.

Time does not permit us to go into this question here and now. But one might suppose that behaviourism, as a target for so much opprobrium, would go underground and that its partisans would be at pains to hide their connection with it. Surprisingly enough, the opposite is alleged to be the case. Locke (1971) has complained, with special reference to Wolpe's behaviour therapy, that some psychologists falsely represent themselves as behaviourists when they are not entitled to this stigma. He points out the danger that, if somebody uses a term like "behaviourism" in a sense that is not its normal one, "behaviourism (defined in the traditional way) will be given credit for something that is not deserved." But what is the traditional meaning of behaviourism? As John Q. Graduate Student will readily discover, this question is far from easy to answer.

The earliest definition appears in the first two sentences of Watson's 1913 article in the Psychological Review: "Psychology as the behaviorist views it is a purely objective experimental branch of natural science. Its theoretical goal is the prediction and control of behavior." As the earliest pronouncement on the subject of the man who coined the term, this must carry a certain authority. Watson went on to write books with titles like Behaviorism (1925) and Psychology from the standpoint of a behaviorist (1919). Readers can be forgiven for identifying behaviourism with the views presented under these titles. But John will note that most of those views had ceased to have any adherents long before the 1970's. In fact, it is doubtful whether anybody other than Watson ever subscribed to them.

Then, John will find that, from about 1930 onwards, a number of theorists appeared who shared Watson's concentration on behaviour as a subject matter for scientific inquiry but otherwise had little in common with him or for that matter with one another, apart from a predilection for carrying out animal experiments and for building theories of learning. In fact, they spent most of their time disagreeing with one another. They were commonly classified, and were apparently not averse from being classified, as behaviourists in a broad sense. But, in order to distinguish their positions from the early behaviourism of Watson, they are frequently and properly called "neo-behaviourists."

In the 1950's and 1960's there were many offshoots of the early neo-behaviourisms in evidence. But there were also writers like Broadbent (1973) or like Miller, Galanter, and Pribram (1960), who accepted classification as behaviourists, even though their ways of thinking departed radically from those of earlier bearers of this designation.

Meanwhile, philosophers made their contributions to the further complication of an already tangled situation. Psychological behaviourisms are often confused with the position known as "philosophical behaviourism," which equates the occurrence of particular mental events or processes with the performance of particular kinds of behaviour (cf. Fodor, 1968). Ryle (1949, p. 327) and some of the philosophers associated with the logical empiricist school have leaned towards it. Traces of it are even to be found in works of such dissimilar philo- 
sophers as Wittgenstein and Sartre. Philosophical behaviourism can derive some encouragement from occasional remarks by Watson, such as that "what psychologists have hitherto called thought is in short nothing but talking to ourselves" (1925, Ch. $\mathrm{X})$. But there is little reason to believe that these philosophical issues were a major preoccupation of Watson's, and neobehaviourists have, on the whole, studiously kept away from them. On the other hand, one philosopher, Quine $(1969$, p. 97), has contended that behaviourism is "just the insistence upon couching all criteria in observation terms ... whose application in each particular case can therefore be checked intersubjectively." He thinks of behaviourism as "covering all reasonable men." This is, of course, going a little too far. The vast majority of reasonable men are not behaviourists, for exactly the same reason as the vast majority of reasonable men are not botanists. But can any reasonable man be an antibotanist?

John Q. Graduate Student will surely by now be forced to the conclusion that, while there can be and have been behaviourist paradigms, behaviourism itself is not a paradigm. This is the conclusion reached by the British philosopher, Briskman (1972), after examining the question carefully. He asserts that behaviourism is a "methodological-cum-metaphysical research programme." Apart from their acceptance of behaviour as their subject matter, behaviourists share a number of working assumptions, some of which are common to all experimental science and some of which are dictated by the fact that behaviourist psychology is psychobiology. It concerns itself with biological aspects of behaviour, with ways in which behaviour contributes to adaptation and ways in which adaptive and maladaptive consequences reflect back on behaviour in their turn. It relates discoveries about behaviour to discoveries made by other branches of biology. Consequently, it is bound to accept the guiding principles that all biology must accept until such time as they are overthrown, including the theory of evolution and the repudiation of vitalism.

So, John will end up with a conception of behaviourism that is so broad that, as several writers including Locke (1971) have objected, the term may become "meaningless and unnecessary." But, if we are to be guided by a survey of the various positions that have been given that name or that have accepted that name, we have no alternative. If behaviourism is neither a sinister conspiracy to subvert society nor the sole hope of solving all society's problems, if it is merely the scientific study of behaviour from a psychobiological point of view, then behaviourism is not only compatible with, but inclusive of, what many, if not most, contemporary psychological researchers are doing, including many who polemicise against behaviourism. But is this point worth dwelling on? If somebody is so hidebound and incapable of keeping up with linguistic change that he prefers to call a toilet a privy, is this not harmless but rather pathetic? Nevertheless, confusions over these points are unfortunately causing trouble for psychology. They are unnecessarily disturbing the public relations of psychology, and they are leading psychologists to spend time on acrimonious wrangles that would be more fruitfully devoted to the constructive advancement of knowledge.

The malaise that is at present afflicting psychology, and from which it has actually never been free, is at least partly verbal in origin. A few years ago, an official of a Canadian Provincial government, a former professor of engineering, made an unkind public attack on psychologists, because he had gathered the impression that they no longer concern themselves primarily with the psyche. This was, of course, exactly as if a psychologist had criticised engineers on the grounds that they no longer confine their attention to engines. If etymology is to be taken seriously, then psychologists should be studying one thing only and that is the physiology of respiration, because the classical Greek word psylche, derived from a verb meaning "to breathe or blow," seems originally to have meant breath or air. It must have been noticed quite early that air is necessary to life and capable of setting objects in motion, and, until the work of Torricelli and Pascal in the 17th century, it was believed that air had no weight and was thus not a true form of matter. The word had come to stand for a much subtler and sophisticated concept, though still retaining traces of its original connotations, by the time of the first Western book on psychology, Aristotle's Peri psykhes, more familiarly known by its Latin title $D e$ 
anima. We all know the rest of the story. Psychology was a sobre, solid branch of philosophy until the last century or so, during which the term has come to stand for a wider assortment of activities than any other occupational label, with the possible exceptions of "civil servant" and "entertainer."

One jazz critic called the late Duke Ellington a "master musician, master psychologist, master choreographer." This is fully consistent with what the word "psychology" means to many laymen, namely the art of influencing people for their benefit, for one's own benefit, or perhaps for mutual benefit. It is an art in the original sense of "skill" or "craft". The term refers to a quite different kind of art when applied, as it frequently is, to the graphic delineation of mental states and of characters by novelists, poets, dramatists, actors and painters. And finally, the word "psychology" is used to denote a variety of scholarly pursuits, sometimes classed as "science," concerned with the formulation of general principles.

There are often quarrels over what kinds of inquiry can be properly called "scientific." We often hear that contemporary psychologists, especially those of a behaviourist bent, have an excessively narrow view of science. Such complaints are usually traceable to some current of thought originating in continental Europe, and it is seldom realised that words like the French scienice or the German Wissenschaft, with their equivalents in other European languages, do not mean what the word science means in English. They are best translated "scholarship." For example, in the continental sense, history, art criticism, and even theology are classed as "scientific" pursuits. In English-speaking countries, the word "science" came to be confined to circumscribed forms of inquiry that concentrate on observable events and the associations among them, with such methodological appurtenances as the confrontation of alternative hypotheses and the segregation of effects of different causal factors through experimental or statistical control.

Psychologists that purport to be scientific, whether in the strict sense or in the wider sense, have at one time or another had three distinet subject-matters. One consists of conscious experiences. Another consists of behaviour. The third con- sists of mental events and processes, not necessarily conscious. This seems to be the subject-matter of psychoanalysis, Chom. skyan psycholinguistics, and some contemporary information-processing approaches to psychology.

Whenever one studies the observable phenomena of human or animal behaviour, one is compelled to refer to unobservable events and processes inside the organism. But throughout history, there seems to have been a division between people who are primarily interested in what is experienced, whether exteroceptively or interoceptively, and those who are inclined to attribute a greater degree of reality and importance to hidden entities whose existence is inferred from what can be experienced. This division between positivists and realists has perturbed psychology from time to time, and the present seems to be one of the times. It is an issue over which many of the greatest minds have exercised themselves, without achieving any resolution, from the disagreements that divided Parmenides and Plato from the Atomists and Epicureans through the medieval debates over the problem of universals and the disputes between the Rationalists and Empiricists in the 17th and 18th centuries. The only new contribution to be found in recent psychological literature is the practice of bombarding those on the other side of the fence with epithets like "trivial," "superficial," "simplistic," and "naive" (e.g., Chomsky, 1968, passim). We must leave it to John Q. Graduate's generation to decide whether this innovation constitutes an intellectual breakthrough or enhances the dignity of our discipline.

The legitimacy of having some people devote themselves to the scientific study of behaviour is nowadays often challenged, and many psychologists show an embarrassed reluctance to acknowledge that this is their speciality. Chomsky's argument that to define psychology as the science of behaviour is like "defining natural science as the science of meter readings" (1968, p. 58) has proved curiously seductive. Deese (1972, p. 12), for example, goes one better and says that it is also like defining chemistry as "the science of observing changes in the colour of paper."

These analogies are singularly ill-chosen on at least two counts. First, meters, like 
litmus paper, would not exist if there were no natural scientists. Secondly, nobody in his right mind is interested in meter readings for their own sake. The physicist examines them in the hope of learning about the ultimate, imperceptible constituents of matter or about other perceptible phenomena, such as thunderstorms and spectral lines. Human behaviour, in contrast, existed long before there were any psychologists, and the troublesome practical and social problems that it causes, apart from other natural sources of interest in it, make it eminently worthy of our attention.

Deese, elsewhere (p. 99), refers to the "realisation that behaviour is only the outward manifestation of what really counts." What really counts is presumably what goes on in people's minds, what they think and feel. But this surely depends on circumstances. Let us suppose that treatment by a clinical psychologist or a psychiatrist caused a patient to behave with perfect rationality and to produce all the verbal and facial expressions of euphoria, while still feeling anxious and depressed. The patient might well regard the outcome as unsatisfactory. But if warfare and violent crimes, acts of prejudice and acts of injustice, continued to be committed by people whose minds were devoid of animosity or erroneous belief (as seems to be more or less the case with some psychopaths and sociopaths), we could hardly feel that the essentials had been dealt with.

Perhaps the most bizarre reproof of all those that are leveled at the investigator of behaviour is the frequently encountered assertion that what he is doing is severely limited and that he leaves out a great deal. Surely, it is in the nature of any branch of science or any intellectual activity to be limited and to leave out a great deal, with the exceptions of Aristotelian and Hegelian philosophy. It has often seemed unfair to me that botanists are spared some of the censure that falls to the lot of the psychologist concerned with behaviour. To read botanical writings, one would think that the world is one large greenhouse. They leave one with the impression that animals and minerals either do not exist at all or are of minor importance. Animals play the briefest of walk-on parts when they nibble at vegetable matter or when their carcases provide nutriment for saprophytic fungi.
The mineral world is absent except when it provided substrates for sessile plants. The whole extraterrestrial cosmos is simply a source of sunlight to support photosynthesis. But in his off-duty hours, the botanist is presumably as inclined as any man to admire the starry sky or to take his children to the zoo. He knows that the study of plant life, or even of a small specialised niche of it, is enough to occupy a busy lifetime. He does not have the time to investigate fundamental problems in zoology, geology, and astrophysics, as well as in botany, and, if he tried to do so, it would all be done badly. But he is not preventing anybody else from pursuing these other concerns.

John Q. Graduate Student will certainly find much to astonish and perplex him as he delves into the methodological controversies of mid-20th-century psychology. And, as he turns more specifically to the critical comments that behaviourism and neo-behaviourism attracted in the early 1970's, his credulity will be strained still further. For example, he will find behaviourism frequently contrasted with cognitive theory, generally to its detriment. But, if there is anybody who is entitled to be called the father of cognitive theory, it is surely Tolman, who was an avowed behaviourist.

John will find the following statement, from an article by Powers (1973, p. 352), far from unique: "Behaviourists have rejected purposes or goals in behaviour because it has seemed that goals are neither observable nor essential." The point, it must be noted, is not that behaviourists have given unsatisfactory accounts of purposes and goals but that they have refused to countenance them at all. John will, of course, be well aware that the word "purpose" appears in the title of Tolman's book (1932) and that many of Hull's theoretical writings (1930, 1931, etc.) were devoted precisely to the analysis of purpose and of goal-seeking.

Locke (1971) questions Wolpe's behaviourist credentials because his therapeutic techniques presupposes the patient's ability to think and image, which are conscious processes. Yet, behaviourist analyses of consciousness include two long articles by Lashley (1923), briefer treatments by Tolman (1932, Ch. XIII) and by Dollard and Miller (1950, Ch. XII), and a major book by J. G. Taylor (1962). Even Watson's posi- 
tion, with its elaborate theory of thinking and its epiphenomenalism, acknowledges the dependence of at least some behaviour on internal events that are accompanied by consciousness.

John's puzzlement over these and similar oddities will bedevil him until he ultimately discovers two historical quirks that seem to have been in large measure responsible for them. One is the failure of surprisingly many polemicists to realise that Watson's behaviourism faded out by about 1930 and was replaced by a variety of neo-behaviourisms differing from it quite radically (see Berlyne, 1968). The second is the widespread tendency during the late 1960's and the early 1970's for behaviourism to be equated with the views of $B$. F. Skinner, or more frequently, with some not altogether accurate representation of Skinner's views. Things reached the point where any objection to Skinner was regarded as a refutation of behaviourism and any attempt to defend behaviourism was assumed to mean agreement with Skinner's assertions. Yet, John will have gained enough historical perspective to recognise Skinner as, in many ways, a highly unusual behaviourist and an extremely atypical neo-behaviourist. He will find the widespread notion that Skinner and behaviourism are synonymous a very strange one.

\section{HULL}

Finally, John's historical researches will bring him up against the crowning and most baffling mystery of all, namely how on earth anybody in 1975 could have had the nerve to produce a paper with the title of this one. John will know that Hull and his associates were responsible for a neo-behaviourist current that was at one time much more influential than any other and certainly more ambitious. It was marked by three stages. First, its finest moments are felt by many to reside in Hull's theoretical papers of the 1930's and the Yale group's forays into social psychology and psychopathology in the 1940's. Next, Hull (1943, 1952) concentrated on the construction of an elaborate, systematic theory of behaviour. And in the final phase, beginning in Hull's last years but embodied particularly in the contributions of Spence (e.g., 1956) and his former students after Hull's death, a few specific learning situations were investi- gated with a view to maximum quantitative rigour. Some commentators feel that this final phase threw out the baby and kept the bath water. Bath water is certainly not to be disparaged. Civilisation would be at a low ebb without it. But there are more interesting commodities, including babies.

The reasons why Hullian neo-behaviourism had largely fallen out of favour by the fourth quarter of the twentieth century will not be hard to find. Hull's postulate system turned out on examination to fall woefully short of his ideals of consistency and unambiguous testable prediction (see Koch, 1954). Considering what Newton had accomplished with three laws of motion and one principle of universal gravitation, his hope of accounting for the whole of mammalian behaviour with 16 to 18 postulates may not have seemed unreasonable at the time. But a generation later, the whole enterprise appeared ingenuous. Psychological processes, it became evident, do not possess the manifest tidiness of the Italianate garden or the Keplerian solar system but the luxuriant hidden order of the tropical rain forest or the central nervous system. Hull's attempts at experimental control of learned behaviour have been surpassed by Skinner and his associates and his attempts at theoretical rigour by the mathematical learning modellers and exponents of computer simulation. Many experimental findings have come to light that his line of thinking would be hard pressed to encompass. And the weight of evidence has gradually tipped the balance against his motivation theory and his conception of reinforcement as drive reduction (Berlyne, 1967).

So, to advocate a return to Hull, as my title might suggest I am doing, would be to invite ridicule. His work grew out of a particular conjuncture of historical circumstances. It played its part in the development of our discipline, but there were good and clear reasons for its supersession.

My title is, however, easily explained. It stems from two common human failings, namely a tendency to treat serious matters facetiously and a tendency to lose control of one's language at times of exasperation.

But I would like simply to point out three features of Hullian behaviour theory that have vanished from the psychological scene 
and to suggest that this is a pity. The reference is to Hull's earlier rather than later work, to the questions he asked rather than to the answers he gave, and to his aims rather than to the ways in which he sought to fulfil them. These features are absent alike from Skinnerian radical behaviourism and from the writings of most present-day cognitive theorists and humanistic psychologists.

\section{Integration}

First, one of Hull's prime objectives, in his heyday, was integration. His theory drew sustenance not only from Watson, Pavlov and Thorndike, its lineal ancestors, but also from psychoanalysis, from the mainstream and offshoots of Gestalt psychology, and from other sources. He intended it to encompass not only all forms of animal and human learning, but all human behaviour from child development to thought processes, from social interaction to psychopathology. He aspired to furnish a store of concepts and principles that could synthesize the various fields of psychology and facilitate the revelation of unity underlying diversity that has always been a central function of science as of art. Such ambitions have now all but faded away. Skinnerians preserve the hope of accounting for virtually the whole of behaviour with the help of a sparse explanatory armoury, but not the eagerness to benefit from what other schools of thought and experimental approaches may have to offer. Most experimental psychologists, including most contemporary heirs of the Hull-Spence tradition, are content with circumscribed theoretical models that are meant to fit stringently limited situations.

Many writers are expressing uneasiness over the fragmentation of psychology into a gravel of esoterically narrow specialities. But the remedy that is all too often proposed is the wrong kind of integration, namely the combination of the empirical investigation of behaviour with other activities, such as the study of conscious experience or the composition of inspirational literature. Estimable though these other activities may be, their aims and methods are so different from those of the empirical investigation of behaviour that attempts at amalgamation can only work to the mutual detriment of all.
Some of the factors that discourage efforts after synthesis and integration are clear. Many have been frightened off by the grandiose failure of Hull's system building, as of the equally comprehensive attempts of his predecessors like Wundt, Freud and McDougall. Data and theoretical ideas have proliferated so feverishly that nobody can have the time to absorb more than a small fraction with accuracy, let alone the panoramic vision required for successful theoretical synthesis.

And, then, there is the bogey of "reductionism." A symposium on the shortcomings of reductionism was published a few years ago under the editorship of Koestler and Smythies (1969). In looking through this book, I have not been able to find any statement of precisely what the term denotes. But one is left with a distinct impression that it means something wrong and evil, and many texts and instructors are evidently transmitting this impression to a whole generation of psychology students.

The term "reductionism" seems to stand for several distinguishable positions in recent philosophical and psychological literature. Sometimes, it is a synonym for positivism, the view, which was discussed a little while ago, that scientific theories boil down to, or ought to boil down to, statements about observable events. Secondly, the word is sometimes applied to the view, which many people still feel it necessary to inveigh against, that every stimulus element, response or intraorganismic event acts in complete isolation from any others that are occurring at the time time. After the belabourings it has received at the hands of the Gestalt school and of many earlier and later writers, this is surely the deadest of Victorian draft horses, if indeed it ever lived. Pavlov is perhaps held up more often than anybody else as the archspokesman of "reductionism" in this sense, which is ironic. Pavlov became famous, long before he worked on conditioned reflexes, for his work on circulatory and digestive processes (for which he was awarded the Nobel Prize for Physiology or Medicine in 1904). The main innovative feature of this work was his advocacy of in vivo experiments with chronic preparations, i.e., of studying the functions of particular organs or systems in the intact animal. He insisted on this kind of technique (which 
was also used in his later research on "higher nervous activity") because he maintained that the activity of any part of the organism is profoundly affected by what is going on in other parts and by the overall state of the organism (Asratyan, 1949)! And surely, every undergraduate whose studies have carried him as far as analysis of variance has discovered that independent variables can have significant interactions!

But in the sense that is most pertinent here, "reductionism" seems to mean what used to be called the "unity of science" and regarded as an obvious ultimate goal of the whole scientific enterprise. One distinguished philosopher of science, Nagel (1961, p. $338)$, defines "reduction", in the sense, as "the explanation of a theory or a set of experimental laws established in one area of inquiry by a theory ... formulated for some other domain." Some of the most celebrated triumphs in the history of science seem to conform to this definition, including Newton's reduction of celestial mechanics to terrestrial mechanics, Darwin's reduction of biology to Malthusian economics, the reduction of much of chemistry to quantum theory in the twentieth century, and the reduction of genetics and cellular biology to molecular biochemistry in the last 20 years.

Several philosophers of science, notably Harmé (1972), have recently been emphasising the essential role in science of structural explanations. These are explanations referring to relations among micro-components or, in other words, entities belonging to a more fine-grained level of analysis than the phenomena to be explained. They depend, in other words, on reduction. Their psychological importance is confirmed by the latest work of Piaget's group on the development of causal explanation in the child (Piaget \& Garcia, 1971).

\section{Motivation}

Secondly, as Spence once said, a frequently overlooked difference between Hull and Skinner is that Hull was really more interested in motivation than in learning. Attempts at defining motivation invariably end up as enumerations of motivational problems or phenomena. Like other writers, I have presented my own lists elsewhere (Berlyne, 1965, Ch. 9; 1970, 1973). It may also help to bring in the distinctions that have become apparent between the diffuse systems of the brain that subserve affective and attentional processes and the specific systems that control the fine details of per. ception and bodily movement. Finally, it is worth bearing in mind that motivational principles form part of what is needed to derive statements about performance from statements about competence.

But for our present purpose, the most instructive reference point may be the law governing insanity pleas in criminal cases. Forensic practice is undergoing overdue changes in English-speaking jurisdictions. But at one time, there was a great deal of talk about "irresistible impulse." The key question, it was suggested, was whether the accused would have done it with a policeman at his elbow.

We ought similarly, I suggest, to form the habit of asking what a subject would do without a psychologist at his elbow. We have vast bodies of enlightening literature on what people see or hear when a psychologist tells them what to look at or listen to, on the course taken by their thought processes when a psychologist tells them what to think about, on what they recall when a psychologist tells them what to reproduce from memory or has told them what to learn. I would be the last to insinuate that researches with verbal instructions do not illuminate psychological functioning outside the laboratory. But they are a little like investigating the flight of birds by launching them into the air with a catapult.

An adequate theory of motivation must identify the conditions that generate pleasure and discomfort, that incite people and animals to action or reduce them to quiescence, that give something reward value or punishment value, that determine what goal or purpose will be adopted. It must analyse the part played by these factors in spontaneous, as well as instructed, behaviour. It must have something to say about the forms of motivation, bound up with basic biological needs, that human beings share with animals, as well as about the uniquely human forms of motivation that underlie social interaction and social organisation, work and play, philosophy, science and art. Some researchers are doing one or other of these. Few are doing all of them. The compliance with which human beings and computers will accept instructions is inducing most specialists in cognitive processes to 
ignore motivational questions completely. Skinnerians are gathering copious information on how the scheduling of reinforcing events affects behaviour. But they are neglecting such questions as why some events have reinforcement value while others do not, and how the effectiveness of a reinforcer may vary with an organism's motivational state.

\section{Symbolic Processes}

Thirdly, the neo-behaviourists of the Hullian current began to build up a theory of cognitive processes, although they were not partial to that particular term, that avoided the two untenable extremes that are prevalent in today's psychology. On the one hand, there are some who overlook the vast and important differences between behaviour that is governed by beliefs, thoughts, and rationally formulated intentions and behaviour that is not. Consequently, values like freedom, dignity, and reason are slighted. On the other hand, there are those who see cognitive processes everywhere, in defiance of the evidence and of Occam's razor. Enthusiasm for the cognitivist cause is all too often accompanied by uncritical advocacy of psychophysical interactionism, of freewill, and of vitalism, in utter disregard of the difficulties that have been found with these positions over the centuries. Anybody is, of course, entitled to uphold these positions if he can point to deficiencies in the criticisms that they have repeatedly attracted. But he is surely not entitled to write as if the counter-arguments had never been brought up at all.

The contention that behaviour depends on cognition encourages neglect of the need to state explicitly the principles that lead to the one from the other. What may seem reasonable assumptions about the connections between what people say and what people do can be highly dubious. Specialists in social psychology (Fishbein \& Ajzen, 1974), in market research (O'Brien, 1971), and in psychological aesthetics (Berlyne, $1971,1974)$, are beginning to realise that nonverbal responses are not always related to verbally expressed judgments in the ways one would expect.

Above all, both overestimation and underestimation of human rationality and ability to act autonomously, regardless of environmental influences, can have undesirable social and political effects. If we fail to appreciate the contrasts between behaviour resulting from informed, rational conviction and behaviour that reflects unthinking, uncritical submission to environmental and social pressure, we may weaken resistance to the blandishments and manipulations of advertisers, politicians and partisans of obscurantist ideologies. But if, on the other hand, we do not face the evidence that much behaviour is automatic and unthinking, we may do too little to guard against the human weaknesses, whether inherited or learned, that conduce to guillibility, destructiveness and cruelty.

We need theoretical analyses that take account of the immense, socially and biologically crucial differences between those forms of behaviour that are voluntary, rational and accompanied by awareness and those forms of behaviour that are not. We need defining criteria that enable these kinds of behaviour to be differentiated by an external observer. We need to distinguish the occasions when Occam's razor leaves us no grounds for inferring the intervention of cognitions or thought processes and the occasions when we are compelled to assume that they are at work. Finally, we need to relate the higher, characteristically human forms of behaviour to the lower and more primitive forms from which our psychobiological point of view compels us to assume that they have developed.

Hull and those influenced by him built up a conception of mediating symbolic processes that was on its way to fulfilling these requirements (see Berlyne, 1965). It merged smoothly with the analyses of signs and symbols that American philosophers of the semiotic movement, from Charles Sanders Peirce to Charles Morris, had worked out over the decades. It also had much in common with the theories of ideationally controlled behaviour produced by Piaget and by Soviet psychologists under the joint influence of Pavlov's writings on the second signal system and Vygotski's research on the intellectual development of the child. Like the Hullians and the semioticians, these European theorists have viewed symbolic mediators as derivatives of overt acts, rather than wrapping them in impenetrable mystery, thus paving the way for a psychology that is both humanistic and scientific. 
Since the decline in popularity of Hull's neo-behaviourism, there has been growing evidence that he was on the right track in these respects. Several lines of research are beginning to call unmistakably for a multi-level view of learning and behaviour, according to which behaviour-controlling mechanisms of increasing complexity are successively superimposed on one another in the course of evolution and in the course of individual development. These mechanisms obey cormmon principles to some extent and distinct principles to some extent. And symbolic or cognitive functions are found only at the highest levels. Support for such a multi-level view comes from data on the ontogenetic development of learning that have been reviewed with reference to animals by Thompson (1968) and with reference to children by White (1965), from data on the successive appearance of different forms of learning in the course of evolution that have been reviewed by Voronin (1972) and especially by Razran (1971), and from data on the successive involvement of different levels of the brain in the course of a single piece of learning that have been gathered by Olds (1973).

\section{ENVOI}

But as I explained earlier, it must not be thought that I am recommending a back-toHull movement. Psychologists as a group are extremely fashion-conscious. Some read their technical journals in the same spirit as other people read Vogue. That many disputes now dividing psychologists are essentially rehashes of debates that have gone on for centuries, or in some cases for millennia, is hardly an original observation. In psychology, as in clothing, there is a limited number of possibilities. Nether garments must be based on the trousers principle, the skirt principle, or the loin-cloth principle, and, in each case, there is a finite number of discriminable graduations between floor length and zero. There is continuous oscillation among the possible alternatives, but there has to be some passage of time before what was once grotesquely frumpish can reappear as the refreshingly unconventional.

And then, there is the compelling argument used by Freud (1912) in his article on why the psychoanalyst should not take notes during the therapeutic session: if the patient has said anything of any importance, the therapist is bound to be reminded of it sooner or later.

\section{REFERENCES}

Astratyan, E. A. I. P. Pavlov. Moscow: USSR Academy of Sciences, 1949. I. $P$. Pavlov. Moscow: Foreign Languages Publishing House, 1953.

Berlyne, D. E. Structure and direction in thinking. New York: Wiley, 1965.

Berlyne, D. E. Arousal and reinforcement. In D. Levine (Ed.), Nebraska Symposium on Motivation, 1967. Lincoln, Nebraska: University of Nebraska Press, 1967. Pp. 1-110.

Berlyne, D. E. Behaviour theory as personality theory. In E. F. Borgatta $\&$ W. W. Lambert (Eds.), Handbook of personality theory and research. Chicago: Rand McNally, 1968, Pp. 629-690.

Berlyne, D. E. Motivational problems. In J. Linhart (Ed.), Proceedings of the International Conference on Psychology of Human Learning. Prague: Institute of Psychology, Czechoslovak Academy of Sciences, 1970, Vol. 1 Pp. 155-176.

Berlyne, D. E. Aesthetics and psychobiology. New York: Appleton-Century-Crofts, 1971.

Berlyne, D. E. The vicissitudes of apla pathematic and thelematoscopic pneumatology (or The hydrography of hedonism). In D. E. Berlyne \& K. B. Madsen (Eds.); Pleasure, reward, preference. New York: Academic Press, 1973. Pp. 1-33.

Berlyne, D. E. (Ed.). Studies in the new experimental aesthetics: Steps towards an objective psychology of aesthetic appreciation. Washington, D.C.: Hemisphere, 1974.

Boneau, C. A. Paradigm regained? Cognitive behaviourism restated. American Psychologist, 1974, 29, 297-309.

Briskman, L. B. Is a Kuhnian analysis applicable to psychology? Science Studies, $1972,2,87-97$.

Broadbent, D. E. In defence of empirical psychology. London: Methuen, 1973.

Chomsky, N. Language and mind. New York: Harcourt Brace, 1968.

Deese, J. Psychology as science and art. New York: Harcourt Brace, 1972.

Dember, W. N. Motivation and the cognitive revolution. American Psychologist, 1974, 29, 161-168.

Dollard, J., \& Miller, N. E. Personality and psychotherapy. New York: McGraw-Hill, 1950.

Fisbein, M., \& Ajzen, I. Attitudes toward objects as predictors of single and multiple behavioural criteria. Psychological Review, 1974, 81, 59-74. 
Fodor, J. A. Psychological explanation. New York: Random House, 1968.

Freud, S. Rathschläge für den Arzt bei der psychoanalytischen Behandlung. Zentralblätt für Psychoanalyse, 1912, 2, 483-489. Recommendations to physicians practising psychoanalysis. In Collected papers, Vol. 2. London: Hogarth, 1924.

Gardiner, W. C. An invitation to cognitive psychology. Monterey: Brooks/Cole, 1973.

Giorgi, A. Psychology as a human science. New York: Harper \& Row, 1970.

Harré, R. The philosophies of science. London: Oxford University Press, 1972.

Hull, C. L. Knowledge and purpose as habit mechanisms. Psychological Review, 1930, 37, 511-525.

Hull, C. L. Goal attraction and directing ideas conceived as habit phenomena. Psychological Review, 1931, 38, 487-506.

Hull, C. L. Principles of behavior. New York: Appleton-Century, 1943.

Hull, C. L. A behavior system. New Haven: Yale University Press, 1952.

Koch, S. Clark L. Hull. In W. K. Estes, et al., (Eds.), Modern learning theory. New York: Appleton-Century, 1954.

Koestler, A. The ghost in the machine. London: Hutchinson, 1967.

Koestler, A., \& Smythies, J. K. Beyond reductionism: New Perspectives in the life sciences. London: Hutchinson, 1969.

Kuhn, T. S. The structure of scientific revolutions. Chicago: University of Chicago Press, 1962.

Lashley, K. S. The behavioristic conception of consciousness. Psychological $R e$ view, 1923, 30, 237-272; 329-352.

Locke, E. A. Is "behavior therapy" behavioristic? Psychological Bulletin, 1971, 76, 318-327.

Miller, C. A., Galanter, E., \& Pribram, K. H. Plans and the structure of behavior. New York: Holt, 1960.

Nagel, E. The structure of science. New York: Harcourt Brace, 1961.

O'Brien, T. Stages of consumer decision making. Journal of Marketing Research, 1971, 8, 283-289.

Olds, J. Brain mechanisms of reinforcement learning. In D. E. Berlyne \& K. B. Madsen (Eds.), Pleasure, reward, preference. New York: Academic Press, 1973.
Palermo, D. Is a scientific revolution taking place in psychology? Science Studies, 1971, 1, 135-155.

Piaget, J., \& Garcia, R. Les explications causales. Paris: Presses Universitaires de France, 1971.

Powers, W. T. Feedback: Beyond behaviorism. Science, 1973, 179, 351-356.

Quine, W. V. O. Linguistics and philosophy. In S. Hook (Ed.), Language and philosophy. New York: New York University Press, 1969.

Razran, G. Mind in evolution. Boston: Houghton Mifflin, 1971.

Rowan, J. Review of I. L. Child: Human istic psychology and the research tradition. British Journal of Psychology, 1973, 64, 647-648.

Ryle, G. The concept of mind. London: Hutchinson, 1949.

Spearman, C. Prychology down the ages, Vol. 1. London: Macmillan, 1937.

Spence, K. W. Behavior theory and conditioning. New Haven: Yale University Press, 1956.

Taylor, J. G. The behavioral basis of perception. New Haven: Yale University Press, 1962.

Thompson, W. R. Development and the biophysical bases of personality. In E. F. Borgatta \& W. W. Lambert (Eds.), Handbook of personality theory and research. Chicago: Rand McNally, 1968.

Tolman, E. C. Purposive behavior in animals and men. New York: Appleton-Century, 1932.

Voronin. L. G. Stages in the evolution of higher nervous activity. In L. G. Voronin (Ed.), Analiz assotsiativnoy deiatel'nosti golounogo mozga, No. 1. Moscow: Moscow University. Press, 1972. (English translation in Soviet Psychology and Psy. chiatry, 1973, 11, 93-112.)

Watson, J. B. Psychology as the behaviorist views it. Psychological Review, 1913, 20, 158-177.

Watson, J. B. Psychology from the standpoint of $a$ behaviorist. Philadelphia: Lippincott, 1919.

Watson, J. B. Behaviorism. New York: People's Institute, 1925.

White, S. H. Evidence for a hierarchical arrangement of learning processes. In $\mathbf{L}$. $\mathbf{P}$. Lipsitt \& C. C. Spiker (Eds.), Advances in child development and behavior, vol. 2. New York: Academic Press, 1965. 